ATTHULAB:

Islamic Religion Teaching \& Learning Journal

Volume 5 Nomor 1 Tahun 2020

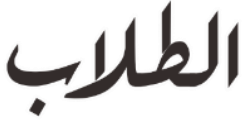

http://journal.uinsgd.ac.id./index.php/atthulab/

\title{
Implementasi Pendidikan Karakter Berbasis Islam dalam Kurikulum Pembelajaran SMK
}

\author{
Ali Miftakhu Rosyad \\ Fakultas Agama Islam, Universitas Wiralodra Indramayu \\ Jl. Ir. H Juanda KM. 03, Karanganyar, Kabupaten Indramayu, Jawa Barat, Indonesia \\ Email: miftakhurosyad@gmail.com
}

\begin{abstract}
This article aims to investigate the process of implementation of character education within the learning curriculum. The essence of implementation of character education within formal education involves various parties simultaneously. The research method conducted is a qualitative approach with case study type. Data collection techniques were interviews, observation, and study of documentation. The results showed that the implementation of character education is the responsibility of all subjects that have been programmed through core competencies, the implementation of character education is carried out through exemplary and habituation processes, evaluation of character education is carried out by the test and non-test methods.
\end{abstract}

Keywords:

character education; learnind curriculum; Islamic education

\begin{abstract}
Abstrak: Artikel ini bertujuan untuk menginvestigasi proses implementasi pendidikan karakter berbasis nilai-nilai ajaran Islam dalam kurikulum pembelajaran. Pada esensinya pelaksanaan pendidikan karakter dalam pendidikan formal melibatkan berbagai pihak secara simultan. Metode penelitian yang digunakan adalah pendekatan kualittif dengan jenis studi kasus. Teknik pengumpulan data dilakukan melalui wawancara, observasi, dan studi dokumentasi. Hasil penelitian menunjukan bahwa implementasi pendidikan karakter menjadi tanggung jawab semua mata pelajaran yang sudah terprogram melalui kompetensi inti, pelaksanaan pendidikan karakter dilakukan melalui proses keteladanan dan pembiasaan, evaluasi pendidikan karakter dilakukan dengan metode test dan non test.
\end{abstract}

Kata kuci:

Pendidikan karakter; kurikulum pembelajaran; pendidikan Islam

DOI: http://dx.doi.org/10.15575/ath.v5i1.7498

Received: 01, 2020. Accepted: 04, 2020. Published: 04, 2020.

\section{PENDAHULUAN}

Secara normtif pendidikan karakter adalah bagian dari proses sosial yang berusaha menanamkan kesadaran kepada siswa agar mengerti tentang nilai-nilai kebaikan yang ada dalam kehidupan sosial, mengerti pola perilaku, norma sopan santun dan tata krama yang dihargai dalam masyarakat. Dengan demikian, kelak saat para peserta didik terjun ke dalam masyarakat, mereka tidak mengalami kesulitan dalam pergaulan, dalam rangka pengembangan kehidupan profesional mereka sebagai orang-orang dewasa dan bertanggung jawab (A, 2012). Kondisi sosio-kultural yang semakin berubah akan menuntut dunia pendidikan dapat menyesuaikan dengan arus perubahan sosial tersebut.

Utuk memperbaiki proses sosial dalam konteks pendidikan, pemerintah juga telah memosisikan pendidikan karakter sebagai misi pertama dari delapan 
misi guna mewujudkan visi pembangunan nasional. Demikian yang tercantum dalam Rencana Pembangunan Jangka Panjang Nasional Tahun 2005-2025, yaitu: terwujudnya karakter bangsa yang tangguh, kompetitif, berakhlak mulia, dan bermoral berdasarkan Pancasila yang dicirikan dengan watak dan perilaku manusia dan masyarakat Indonesia yang beragam, beriman dan bertakwa kepada Tuhan Yang Maha Esa, berbudi luhur, bertoleran, bergotong-royong, berjiwa patriotik, berkembang dinamis, dan berorientasi iptek (Undang-Undang No. 17 Tahun 2007 tentang Rencana Pembangunan Jangka Panjang Nasional) (Palunga \& Marzuki, 2017). Sebagai negara yang multikultural, Indonesia memiliki nilai-nilai kearifan lokal yang sangat kaya raya baik dalam skala nasional dan lokal, hal seperti itu harus disosialisasikan sedini mungkin dalam pendidikan.

Dewasa ini bangsa Indonesia sedang melakukan pembenahan Sumber Daya Manusia (SDM) terutama dalam bidang pendidikan. Diawali dari perubahan kurikulum yang dipandang oleh banyak kalangan pendidik sebagai perubahan yang sangat drastis, sejak terjadinya Era reformasi yang ditandai oleh berakhirnya kekuasaan orde baru bangsa Indonesia mengalami empat kali perubahan kurikulum, dari KBK, Kurikulum 2004, Kurikulum 2006 yang operasionalnya dikenal sebagai Kurikulum Tingkat Satuan Pendidikan (KTSP) dan Kurikulum 2013. Salah satu keunikan dari Kurikulum 2013 adalah kurikulum ini lebih menekankan pentingnya aktualisasi pendidikan karakter dengan mengintegrasikan pada semua mata pelajaran, karena KI 1 dan KI 2 setiap mata pelajaran memandatkan kepada pendidik untuk membentuk kompetensi sikap baik sikap spiritual dan sikap sosial.

Salah satu faktor penting yang akan menentukan jalanya pendidikan adalah peranan kurikulum. Tidak dapat dipungkiri juga perubahan kurikulum juga merupakan akibat dari perkembangan masyarakat. Bangsa Indonesia tidak menginginkan dalam mencerdaskan generasinya yang tidak sesuai dengan kebutuhan zaman tersebut. Kita mendidik generasi yang akan hidup di zaman yang berbeda dengan kita. Kita mendewasakan mereka melalui pendidikan yang tidak usang yang muatannya tertuang di dalam kurikulum(Sukmadinata \& Muchlis, 2000). Dalam suatu sistim pendidikan, kurikulum itu sifatnya dinamis serta harus selalu dilakukan perubahan dan pengembangan, agar dapat mengikuti iklim dan atmosphir sebuah pendidikan(Mulyasa, 2013). Perubahan kurikulum pendidikan suatu negara biasanya diprakarsai oleh kementerian pendidikan. Menteri Pendidikan dan Kebudayaan, Muhammad Nuh mengatakan akan konsisten dan terus maju dengan rencana implementasi kurikulum 2013 meskipun kritik dan protes datang bertubi-tubi dari berbagai kalangan. Umumnya kritik-kritik tersebut datang dari guru, pendidik dan pemerhati pendidikan. Menurut Muhammad Nuh, mutu pendidikan Indonesia akan terus memburuk kalau kurikulum baru ini tidak dilaksanakan.

Berdasarkan catatan sejarah beberapa tahun silam yang pernah terjadi pada tahun pelajaran 2014/2015 telah mulai diberlakukan Kurikulum 2013 di seluruh Indonesia yang merupakan pembaharuan dan penyempurnaan Kurikulum 2006. Karakteristik dasar Kurikulum 2013 adalah terletak pada 
pendekatan yang digunakan dalam pengembangan kurikulum tersebut. Kurikulum 2013 menekankan pendekatan saintifik pada jenjang pendidikan dasar hingga menengah. Implementasi memiliki tujuan untuk meningkatkan kualitas sumber daya manusia dan meningkatkan daya saing bangsa seiring dengan perkembangan ilmu pengetahuan, teknologi, dan seni. Penerapan Kurikulum 2013 diharapkan dapat menghasilkan sumber daya manusia yang produktif, kreatif inovatif dan afektif, melalui penguatan kompetensi sikap, pengetahuan, dan keterampilan (Palobo \& Tembang, 2019).

Fakta yang terjadi dewasa ini bahwa Kurikulum 2013, sebagaimana Menteri Pendidikan dan Kebudayaan telah jelaskan, merupakan perbaikan dari kurikulum 2004 dan 2006, yang merupakan kurikulum berbasis sekolah dan berbasis kompetensi. Namun, guru masih sedang mempelajari bagaimana melaksanakan kurikulum 2006. Sangat disesalkan, kebanyakan guru dan masyarakat umum tidak diinformasikan apa yang sebenarnya tidak beres dengan kurikulum 2006 atau KTSP(Ahmad, 2014). Pemerintah seharusnya telah mempublikasikan data hasil evaluasi untuk mengidentifikasikan aspek mana kurikulum 2013 yang bermasalah. Data semacam itu akan membuat perubahan kurikulum lebih masuk akal.

Hasil penelitian yang telah dilakukan oleh Hari Setiadi menunjukan bahwa letak kesulitan pelaksanaan Pendidikan karakter versi Kurikulum 2013 selain aspek pelaksanaan adalah pada aspek penilaian. Penilaian hasil belajar oleh satuan pendidikan bertujuan menilai pencapaian Standar Kompetensi Lulusan untuk semua mata pelajaran dengan mempertimbangkan hasil penilaian peserta didik oleh pendidik(Setiadi, 2016). Penilaian hasil belajar pada Kurikulum 2013 ini dilakukan oleh pendidik dan satuan pendidik melalui tahapan mengkaji silabus sebagai acuan perencanaan penilaian, pembuatan kisikisi instrumen dan penetapan kriteria penilaian, pelaksanaan penilaian dalam proses pembelajaran, menganalisis hasil penilaian dan memberi tindak lanjut atas penilaian yang dilakukan oleh pendidik, menyusun laporan hasil penilaian dalam bentuk deskripsi pencapaian kompetensi dan deskripsi sikap.

Hasil penelitian lain yang telah dilakukan oleh Buchari dan Swadayani menunjukan bahwa pendidikan karakter dalam konteks pelaksanaan menjadi tanggung jawab kepala sekolah yang dibantu oleh wakil kepala sekolah dan semua guru. Namun dalam konteks pelaksanaanya pendidikan karakter melibatkan semua pihak yang ada di sekolah seperti pendidik dan tenaga kependidikan dan di bantu oleh masyarakat(Buchory \& Swadayani, 2014). Dala penelitian ini akan mencoba memfokuskan kajianya mengenai keterkaitan kurikulum pendidikan dan pendidikan islam dalam menciptakan suasana pendidikan karakter melalui berbagai pendekatan yang dilakukan melalui kegiatan pembelajaran di kelas dan luar kelas.

Penelitian yang telah dilaksanakan di SMK Muhammadiyah Juntinyuat Kabupaten Indramayu menunjukan bahwa pelaksanaan pendidikan karakter berbasis nilai-nilai Islam masih belum optimal dilakukan baik dari segi perencanaan, proses maupun evalusinya. Dalam melaksanakan pembelajaran dengan Kurikulum 2013, guru belum mengoptimalkan pendekatan saintifik 
yang meliputi mengamati, menanya, mengumpulkan data, mengasosiasi dan mengomunikasikan. Hal ini terlihat dalam kegiatan pembelajaran dengan metode ceramah dan diskusi, guru menjelaskan materi pembelajaran kemudian menugaskan siswa untuk berkelompok mengerjakan soal. Setelah mengerjakan soal yang sesuai dengan materi yang telah dijelaskan siswa ditugaskan untuk mempresentasikan hasil. Pada saat presentasi ada siswa yang mendominasi tetapi ada juga siswa yang kurang termotivasi dalam pembelajaran. Kegiatan selanjutnya adalah memberikan kesempatan kepada siswa kelompok lain untuk mempresentasikan hasil. Proses pembelajaran tersebut menyebabkan tidak semua siswa dapat mengonstruk kompetensi pengetahuan, sikap (yang termasuk ranah afektif termasuk: nilai, motivasi, kesadaran diri dll) dan keterampilannya.

Dengan alasan tersebut sangat perlu sekiranya dilakukan sebuah penelitian mengenai pelaksanaan pendidikan karakter berbasis nilai-nilai Islam dalam Kurikulum 2013. Dikarenakan Kurikulum tersebut lebih menekankan pada pengembangan sikap spiritual dan sikap sosial pada pesera didik. Namun, secara substansinya kurikulum adalah bagian inti yang akan menjadi penunjuk arah terhadap keberhasilan sebuah pendidikan.

\section{METODE PENELITIAN Jenis Penelitian}

Penelitian ini menggunakan kualitatif dengan jenis studi kasus. Studi kasus adalah salah satu jenis pendekatan kualitatif yang penelitianya mengeksplorasi kehidupan nyata, sistem terbatas kontemporer (kasus) atau beragam sistem terbats (berbagai kasus), melalui pengumpulan data yang detail dan mendalam yang melibatkan beragam sumber informasi dan melaporkan deskripsi kasus dan tema kasus terhadap berbagai berbagai peristiwa-peristiwa dan aktivitas yang terjadi di SMK Muhammadiyah Juntinyuat Kabupaten Indramayu(Creswell, 2015). Pendekatan dalam penelitian ini adalah naturalistik artinya peneliti tidak berusaha memanipulasi latar penelitian, tetapi melakukan studi terhadap suatu fenomena/peristiwa. Fokus penelitian dapat berupa orang, kelompok, program, pola hubungan, ataupun interaksi semuanya itu dilihat dalam konteks alamiah. Dengan demikian, peneliti melalui pengalaman peneliti berusaha mengkonstruksi pandangan tentang dunia sekitar(Ghony \& Almanshur, 2012).

\section{Unit Analisis}

Unit analisis dalam penelitian ini adalah (1) perencanaan pendidikan karakter dalam pembelajaran; (2) peran Kurikulum 2013; dan (3) integrasi pendidikan karakter, pendidikan Islam, dan Kurikulum 2013.

\section{Sumber Data}

Sumber data dalam penelitian kualitatif dapat digolongkan menjadi dua yaitu sumber data primer dan sumber data sekunder. Sumber data primer dalam penelitian ini adalah data yang diperoleh langsung dari subyek penelitian 
tentang Implementasi Pendidikan Karakter melalui Kurikulum Pembelajaran Juntinyuat Kabupaten Indramayu. Sedangkan sumber data sekunder adalah sumber data tambahan yang berupa dokumen dan bahan kepustakaan yang dianggap relevan dengan penelitian.

\section{Teknik dan Instrumen Pengumpulan Data}

Dalam konteks penelitian kualitatif, pengumpulan data sering dilakukan dengan melihat kondisi alamiah (natural setting), sumber data primer, dan teknik pengumpulan data lebih banyak pada observasi berperan serta (particifan observation), wawancara mendalam (in depth interview) dan dokumentasi(Sugiyono, 2008). Oleh karena itu, dalam penelitian ini instrumen pengumpul data yang utama adalah (key instrument) yaitu peneliti sendiri. Adapun teknik pengumpulan data yang digunakan dalam penelitian ini adalah:

1. Observasi, dalam hal ini, peneliti terjun langsung ke lokasi penelitian dan ikut berpartisipasi sebagai asisten pembina ekstrakurikuler dalam kegiatan yang terjadi di lingkungan sekolah sambil melakukan pengamatan. Akan tetapi pada saat ada kegiatan yang dilakukan oleh siswa peneliti memberhentikan pengamatan karena berbagai pertimbangan yang menimbulkan dampak seperti mengganggu kegiatan tersebut, sehingga peneliti mengamati dari kejauhan. Observasi dilaksanakan di SMK Muhammadiyah Juntinyuata Kabupaten Indramayu, adapun subjek yang diobservasi antara lain; (a) kegiatan di dalam kelas, seperti proses belajar mengajar, diskusi kelompok. (b) Kegiatan di luar kelas, seperti kegiatan ekstra kulikuler, kegiatan peringatan hari besar islam (PHBI) dan kegiatan guru serta kepala sekolah pada saat berada di luar kelas.

2. Wawancara, dalam penelitian ini bentuk wawancara terhadap informan dengan menggunakan pedoman wawancara yaitu membuat catatan tentang pokok-pokok pertanyaan yang sesuai dengan tujuan penelitian. Berangkat dari pendapat tersebut, peneliti melakukan wawancara dengan dua cara; yaitu wawancara terstruktur, dengan wawancara tidak terstruktur yang ditujukan kepala sekolah, wakil kepala sekolah bidang kesiswaan, guru BK, guru PKN, guru PAI, dan siswa mengenai proses implementasi pendidikan karakter melalui kurikulum pembelajaran di SMK Muhammadiyah Juntinyuat Kabupaten Indramayu. Berikut akan dijelaskan tabel mengenai kisi-kisi wawancara yang digunakan dalam penelitian ini:

3. Dokumentasi dalam penelitian ini adalah suatu proses pengambilan beberapa dokumen yang dijadikan sebagai bukti rasional dan empirik yang terkait dengan tujuan penelitian. Pada tahap ini, peneliti meminta profil sekolah Sekolah SMK Muhammadiyah Juntinyuat sebagai langkah awal untuk melihat kondisi sekolah tersebut.

\section{Teknik Analisis Data}

Menurut Bogdan \& Bike analisis data adalah upaya yang dilakukan dengan bekerja dengan data, mengorganisasi data, memilah-milahnya menjadi satuan data yang dapat dikelola, mensintesiskan data, mencari dan menemukan 
pola, menemukan apa yan penting dan apa yang dipelajari, dan memutuskan apa yang dapat diceritakan kepada orang lain(Moleong, n.d.).

Dalam penelitian ini digunakan teknik analisis model interaktif yaitu dengan menggunakan langkah-langkah sebagai berikut.

1. Pengumpulan data

Data dikumpulkan dengan tujuan untuk memperoleh atau mendapat informasi di lapangan sesuai dengan kebutuhan peneliti dan rumusan masalah sehingga memungkinkan data tersebut harus akurat.

2. Reduksi data

Data yang diperoleh di lapangan semakin bertambah banyak, sehingga perlu dilakukan reduksi, dirangkung, dipilih, diberi kode dan diambil yang penting dari tema dan polanya. Melalui proses reduksi data laporan mentah di lapangan menjadi lebih sistemati sehingga mudah dikendalikan.

3. Penyajian data

Setelah data direduksi maka, langkah berikutnya adalah menyajikan data. Dalam penelitian ini, penyajian data dilakukan dalam bentuk uraian teks yang bersifat deskriptif yang mengungkapkan tentang implementasi pendidikan karakter melalui kurikulum pembelajaran melalui tiga aspek yaitu pengintegrasian pendidikan karakter pada semua mata pelajaran, implementasi pendidikan karakter, dan evaluasi pendidikan karakter. Selain itu, menyajikan data yang berhubungan dengan dukungan komite sekolah, orang tua, dan masyarakat melalui kultur sekolah serta aktualisasi pendidikan karakter malalui kultur sekolah meliputi kegiatan rutinitas, kegiatan spontanitas, keteladanan, dan pengkondisian lingkungan.

4. Pengambilan Simpulan

Pengambilan simpulan dilakukan untuk menyederhanakan data dan informasi yang diperoleh guna mencapai pola, tema, hubungan, persamaan, dan hal-hal lain yang sering timbul. Pengambilan simpulan ini diklarifikasi dan diverifikasi selama penelitian berlangsung.

\section{HASIL PENELITIAN DAN PEMBAHASAN}

Merurut Mulyasa Implementasi pendidikan karakter adalah proses sosialisasi mengenai nilai-nilai ajaran moral yang dilakukan secara menyeluruh dan menyesuaikan dengan situasi dan kondisi lembaga pendidikan. Dalam lingkungan pendidikan formal implementasi menjadi tugas pendidik dan tenaga kependidikan untuk membentuk siswa yang berakhlak mulia(Mulyasa, 2011).

Berdasarkan beberapa pendapat di atas, implementasi adalah suatu sisten rekayasa dalam penerapan atau pelaksanaan sesuatu yang berupa perluasan aktifitas yang saling menyesuaikan. Agar aktifitas penerapan atau pelaksanaan dapat berjalan,membutuhkan manajemen yang baik. Fungsi manajemen menurut Chung dan Magginson, yang dikutip oleh Sugoyono, adalah planning (perencanaan), organizing (pengorganisasian) ,actuating (pelaksanaan), dan controlling (pengawasan/ pengendalian)(Veithzal \& Murni, 2009). 
Berdasar penelitian di SMK Muhammadiyah Juntinyuat, Implementasi pendidikan karakter dalam Kurikulum 2013 melaksanakan tahapan-tahapan yang meliputi tahap pengintegrasian kedalam semua mata pelajaran, tahap pelaksanaan dan tahap evaluasi.

\section{Pendidikan Karakter Terintegrasi dalam Mata Pelajaran}

Terlepas dari berbagai kekurangan dalam praktik pendidikan di Indonesia, apabila dilihat dari Standar Nasional Pendidikan yang menjadi acuan pengembangan kurikulum 2013, dan implementasi pembelajaran dan penilaian di sekolah, tujuan pendidikan di tingkat SD, SMP, dan SMA sebenarnya dapat dicapai dengan baik. Pembinaan karakter juga termasuk dalam materi yang harus diajarkan dan dikuasai serta direalisasikan oleh peserta didik dalam kehidupan sehari-hari. Permasalahannya, pendidikan karakter di sekolah selama ini baru menyentuh pada tingkatan pengenalan norma atau nilai-nilai, dan belum pada tingkatan internalisasi dan tindakan nyata dalam kehidupan sehari-hari(Kurikulum \& Kemdiknas, 2011).

Sebagai upaya untuk meningkatkan kesesuaian dan mutu pendidikan karakter, Kementerian Pendidikan Nasional mengembangkan grand design pendidikan karakter untuk setiap jalur, jenjang, dan jenis satuan pendidikan. Grand design menjadi rujukan konseptual dan operasional pengembangan, pelaksanaan, dan penilaian pada setiap jalur dan jenjang pendidikan. Konfigurasi karakter dalam konteks totalitas proses psikologis dan sosialkultural tersebut dikelompokan dalam: Olah Hati (Spiritual and emotional development), Olah Pikir (intellectual development), Olah Raga dan Kinestetik (Physical and kinestetic development), dan Olah Rasa dan Karsa (Affective and Creativity development)(Zuchdi, 2008). Pengembangan dan implementasi pendidikan karakter perlu dilakukan dengan mengacu pada grand design tersebut.

Menurut UU No 20 Tahun 2003 Tentang Sistem Pendidikan Nasional pada Pasal 13 Ayat 1 menyebutkan bahwa Jalur pendidikan terdiri atas pendidikan formal, nonformal, dan informal yang dapat saling melengkapi dan memperkaya. Pendidikan informal adalah jalur pendidikan keluarga dan lingkungan. Pendidikan informal sesungguhnya memiliki peran dan kontribusi yang sangat besar dalam keberhasilan pendidikan. Peserta didik mengikuti pendidikan di sekolah hanya sekitar 7 jam per hari, atau kurang dari $30 \%$. Selebihnya $(70 \%)$, peserta didik berada dalam keluarga dan lingkungan sekitarnya. Jika dilihat dari aspek kuantitas waktu, pendidikan di sekolah berkontribusi hanya sebesar 30\% terhadap hasil pendidikan peserta didik.

Selama ini, pendidikan informal terutama dalam lingkungan keluarga belum memberikan kontribusi berarti dalam mendukung pencapaian kompetensi dan pembentukan karakter peserta didik. Hal ini disebabkan oleh berbagai hal, diantaranya kesibukan dan aktivitas kerja orang tua yang relatif tinggi, kurangnya pemahaman orang tua dalam mendidik anak di lingkungan keluarga, pengaruh pergaulan di lingkungan sekitar, dan pengaruh media elektronik. Salah satu alternatif untuk mengatasi permasa-lahan tersebut adalah 
melalui pendidikan karakter terpadu, yaitu memadukan dan mengoptimalkan kegiatan pendidikan informal lingkungan keluarga dengan pendidikan formal di sekolah(Heri, 2012). Dalam hal ini, waktu belajar peserta didik di sekolah perlu dioptimal-kan agar peningkatan mutu hasil belajar, terutama pembentukan karakter peserta didik sesuai tujuan pendidikan dapat dicapai.

Pendidikan karakter dapat diintegrasikan dalam pembelajaran pada setiap mata pelajaran. Materi pembelajaran yang berkaitan dengan norma atau nilai-nilai pada setiap mata pelajaran perlu dikembangkan, dieksplisitkan, dikaitkan dengan konteks kehidupan sehari-hari. Dengan demikian, pembelajaran nilai-nilai karakter tidak hanya pada tataran kognitif, tetapi menyentuh pada internalisasi, dan pengamalan nyata dalam kehidupan peserta didik sehari-hari di masyarakat(Samani \& Hariyanto, 2016).

Berdasarkan hasil wawancara, observasi, dan dokumentasi yang dilakukan di SMK Muhammadiyah Juntinyuat Kabupaten Indramayu menunjukan bahwa kegiatan ekstra kurikuler yang selama ini diselenggarakan sekolah merupakan salah satu media yang potensial untuk pembinaan karakter dan peningkatan mutu akademik peserta didik. Kegiatan ekstra kurikuler merupakan kegiatan pendidikan di luar mata pelajaran untuk membantu pengembangan peserta didik sesuai dengan kebutuhan, potensi, bakat, dan minat mereka melalui kegiatan yang secara khusus diselenggarakan oleh pendidik dan atau tenaga kependidikan yang berkemampuan dan berkewenangan di sekolah. Melalui kegiatan ekstra kurikuler diharapkan dapat mengembangkan kemam-puan dan rasa tanggung jawab sosial, serta potensi dan prestasi peserta didik.

Pendidikan karakter di sekolah juga sangat terkait dengan manajemen atau pengelolaan sekolah. Pengelolaan yang dimaksud adalah bagaimana pendidikan karakter direncanakan, dilaksanakan, dan dikendalikan dalam kegiatan-kegiatan pendidikan di sekolah secara memadai. Pengelolaan tersebut meliputi nilai-nilai yang perlu ditanamkan, muatan kurikulum, pembelajaran, penilaian, pendidik dan tenaga kependidikan, dan komponen terkait lainnya. Dengan demikian, manajemen sekolah merupakan salah satu media yang efektif dalam pendidikan karakter di sekolah.

Pendidikan karakter seharusnya membawa peserta didik ke pengenalan nilai secara kognitif, penghayatan nilai secara afektif, dan akhirnya ke pengamalan nilai secara nyata. Permasalahan pendidikan karakter yang selama ini ada di sekolah perlu segera dikaji, dan dicari alternatif-alternatif solusinya, serta perlu dikembangkannya secara lebih operasional sehingga mudah diimplementasikan di sekolah.

Arti pendidikan karakter secara terintegrasi di dalam proses pembelajaran adalah pengenalan nilai-nilai, fasilitasi diperolehnya kesadaran akan pentingnya nilai-nilai, dan penginternalisasian nilai-nilai ke dalam tingkah laku peserta didik sehari-hari melalui proses pembelajaran, baik yang berlangsung di dalam maupun di luar kelas pada semua mata pelajaran. Dengan demikian, kegiatan pembelajaran, selain untuk menjadikan peserta didik menguasai kompetensi (materi) yang ditargetkan, juga dirancang dan dila- 
kukan untuk menjadikan peserta didik mengenal, menyadari/peduli, dan menginter-nalisasi nilai-nilai dan menjadikannya perilaku.

\section{Pelaksanaan Pendidikan Karakter}

Pelaksanaan pembelajaran pada kurikulum 2013 meliputi kegiatan pendahuluan, kegiatan inti, dan kegiatan penutup. Pembelajaran ekonomi pada kurikulum 2013 menggunakan pendekatan saintifik, yaitu pembelajaran yang menekankan pada pentingnya kolaborasi dan kerjasama antar peserta didik dalam menyelesaikan setiap permasalahan dalam pembelajaran. Pendekatan saintifik menekankan pada proses mengamati, menanya, mengumpulkan informasi, mengasosiasikan/mengolah informasi, dan mengkomunikasikan.

\section{Kegiatan Pendahuluan}

Hasil pengamatan dan wawancara dapat diketahui bahwa kegiatan awal atau pembukaan pembelajaran selalu dimulai dengan kegiatan berdoa, tadarus. Materi pelajaran yang diberikan adalah kelangkaan. Materi ini mendeskripsikan mengenai hubungan kelangkaan sumber daya dengan kebutuhan manusia. Dalam kegiatan pendahuluan ini, guru:

1) Menyiapkan peserta didik secara psikis dan fisik untuk mengikuti proses pembelajaran;

2) Mengajukan pertanyaan-pertanyaan tentang materi yang sudah dipelajari dan terkait dengan materi yang akan dipelajari;

3) Mengantarkan peserta didik kepada suatu permasalahan atau tugas yang akan dilakukan untuk mempelajari suatu materi;

4) Menyampaikan garis besar cakupan materi dan menginformasikan KD beserta tujuan pembelajaran yang akan dicapai.

2. Kegiatan Inti

Kegiatan inti merupakan proses pembelajaran untuk mencapai tujuan, yang dilakukan secara interaktif, inspiratif, menyenangkan, menantang, dan memotivasi peserta didik untuk aktif menjadi pencari informasi, serta memberikan ruang yang cukup bagi prakarsa, kreativitas, dan kemandirian sesuai dengan bakat, minat dan perkembangan fisik serta psikologis peserta didik. Kegiatan inti menggunakan metode yang disesuaikan dengan karakteristik peserta didik dan mata pelajaran. Pembelajaran ekonomi pada kurikulum 2013 menggunakan pendekatan saintifik, yaitu pembelajaran yang menekankan pada pentingnya kolaborasi dan kerjasama antara peserta didik dalam menyelesaikan setiap permasalahan dalam pembelajaran. Pendekatan santifik menekankan pada proses mengamati, menanya, mengumpulkan, mengasosiasi / pengolahan informasi, dan mengkomunikasikan.

Dalam mengamati guru membuka secara luas dan bervariasi kesempatan peserta didik untuk melakukan pengamatan melalui kegiatan : melihat, menyimak, mendengar, dan membaca. Peserta didik mengamati dengan melihat gambar atau tayangan video yang berkaitan dengan materi kelangkaan. Peserta didik juga mengamati gambar atau video yang menunjukkan hubungan sumber daya ekonomi dengan kebutuhan manusia. Berdasarkan hasil pengamatan 
dengan melihat gambar/video, masingmasing kelompok mendiskusikan hal-hal yang ingin diketahui. Dalam kegiatan mengamati, selanjutnya guru membuka kesempatan kepada peserta didik untuk bertanya mengenai apa saja yang sudah dilihat, dibaca dan disimak. Guru membimbing peserta didik untuk dapat mengajukan pertanyaan- pertanyaan tentang hasil pengamatan yang sudah dilakukan. Pertanyaan yang bersifat faktual sampai pertanyaan yang bersifat hipotetik. Dari situasi di mana peserta didik masih memerlukan bantuan guru untuk mengajukan pertanyaan sampai ke tingkat dimana peserta didik mampu mengajukan pertanyaan secara mandiri. Melalui kegiatan bertanya dikembangkan rasa ingin tahu peserta didik. Semakin sering dalam bertanya maka rasa ingin tahu semakin dapat dikembangkan. Pertanyaan tersebut menjadi dasar bagi guru untuk memberikan informasi lebih lanjut dan beragam, yang pada kegiatan berikutnya guru memberikan permasalahan kepada peserta didik untuk dipecahkan melalui kegiatan kelompok.

Tindak lanjutnya adalah setiap kelompok diminta menggali atau mengumpulkan informasi untuk menjawab permasalahan yang telah diberikan guru dengan membaca buku, internet atau sumber lain yang relevan. Setiap kelompok mendokumen dari hasil pelacakannya sebagai bahan untuk analisis.

Setiap kelompok menganalisis data yang didapatkan, kemudian merumuskan secara tertulis hasil diskusi kelompoknya. Dari kegiatan tersebut terkumpul sejumlah informasi. Informasi tersebut menjadi dasar bagi kegiatan berikutnya yaitu memproses informasi untuk menemukan keterkaitan satu informasi dengan informasi lainnya untuk menemukan suatu kesimpulan.

Kegiatan berikutnya adalah menuliskan atau mempresentasikan apa yang ditemukan dalam kegiatan mencari informasi, mengasosisasi dan menemukan pola. Guru memilih salah satu kelompok untuk mempresentasikan hasilnya sedangkan kelompok lain diberi kesempatan untuk memberi tanggapan.

\section{Kegiatan Penutup}

Pada kegiatan akhir pembelajaran guru bersama peserta didik menyimpulkan materi kelangkaan yang baru saja disajikan. Guru memberi tugas yang harus dikerjakan (di rumah) kepada peserta didik dalam usaha pendalaman dan pengembangan materi kelangkaan. Guru juga memberitahukan materi yang akan dibahas pada pertemuan berikutnya, karena dalam kurikulum 2013 siswa dituntut untuk tidak hanya diam. Oleh karena itu, siswa harus mengetahui terlebih dahulu materi yang akan dipelajari.

Penilaian hasil belajar oleh pendidik adalah proses pengumpulan informasi / data tentang capaian pembelajaran peserta didik dalam aspek sikap, aspek pengetahuan, dan aspek keterampilan yang dilakukan secara terencana dan sistematis yang dilakukan untuk memantau proses, kemajuan belajar, dan perbaikan hasil belajar melalui penugasan dan evaluasi hasil belajar. Adapun jenis penilaian yang digunakan untuk menilai kompetensi sikap, pengetahuan, dan keterampilan pada pembelajaran kurikulum 2013 adalah: penilaiaan tertulis, penilaiaan kinerja, penilaiaan portofolio, dan peniliaan proyek. Penilaiaan aspek sikap dilakukan melalui observasi / pengamatan keseharian siswa disekolah 
yang dimana guru kelas atau wali kelas yang bertanggung jawab melaporkan hasil penilaian dalam bentuk predikat atau deskripsi. Penilaiaan aspek pengetahuan dilakukan melalui tes tertulis, tes lisan, dan penugasan yang diberikan oleh guru dan hasil penilaian dilaporkan dalam bentuk nilai angka, predikat dan deskripsi pencapaiaan kompetensi mata pelajaran. Sedangkan penilaiaan aspek ketrampilan dilakukan melalui praktik, produk, proyek, portofolio, dan teknik lain yang sesuai dengan kompetensi yang dinilai dan hasil penilaiaan dilaporkan dalam bentuk nilai angka, predikat dan deskripsi pencapaiaan kompetensi mata pelajaran.

\section{Evaluasi pendidikan karakter dalam Kurikulum 2013}

Evaluasi adalah langkah penting yang dilakukan sekolah untuk mengidentifikasi kebe-rhasilan dan tindak lanjut dalam aktualisasi pendidikan karakter melalui kultur sekolah. Evaluasi merupakan bagian yang tak terpisahk-an dari aktualisasi pendidikan karakter berbasis kultur sekolah karena dengan evaluasi dapat diketahui faktor penghambat,faktor pendukung dan bagaimana hubungan aktualisasi nilai-nilai karakter dengan kultur sekolah.

Evaluasi adalah suatu proses penilaian untuk mengambil keputusan yang menggunak-an seperangkat hasil pengukuran dan berpedo-man kepada tujuan yang telah ditetapkan. Evaluasi disini merupakan perpaduan dari penilaian dan pengukuran.(Basuki \& Hariyanto, 2014). Dalam aktualisasi pendidikan karakter di lingkungan sekolah diperlukan langkah akhir yaitu penilaian yang harus dilakukan secara terus menerus dan berkesinambungan, untuk mengetahui dan memantau perubahan serta kemajuan siswa, maupun memberi skor atau nilai yang biasa dikonversi melalui penilaian hasil belajar(Mulyasa, 2013).

Pernyataan tersebut sesuai pendapat Arifin(Arifin, 2013) membagi model-model evaluasi ada 9 yaitu; 1.) model tyler; 2.) model yang berorentasi pada tujuan; 3.) model pengukuran; 4.) model kesesuaian; 5.) educatio-nal system evaluation model; 6.) model alkin; 7.) illuminative model; 8.) Model Brinkerhoff; dan 9.) model responsif. Untuk pengukuran sikap model evaluasi yang digunakaan yaitu model pengukuran. Model pegukuran menitikberatkan pada kegiatan pengukuran yang diguna-kan untuk menentukan kuantitas suatu sifat tertentu yang telah dimiliki oleh objek, orang maupun peristiwa, dalam bentuk unit maupun ukuran tertentu. Dalam dunia pendidikan di sekolah, model ini diterapkan untuk menentuk-an perbedaanperbedaan individual maupun kelompok dalam hal kompetensi, minat, dan sikap. Objek evaluasi dalam model ini adalah tingkah laku peserta didik mencakup hasil belajar (kognitif), pembawaan, sikap, minta, bakat, dan juga aspek-aspek kepribadian peserta didik. Model ini menggunakan pendekatan penilaian acuan norma (PAN) (norm-referenced assessment). Pada penilaian sikap 
maka objek evaluasi adalah peserta didik yang diamati adalah perilaku peserta didik yang mencakup hasil belajar, sikap dan pembawaan peserta didik.

Berdasarkan hasil temuan data di lapangan melalui wawancara, observasi, dan dokumentasi menunjukan bahwa evaluasi pendidikan karakter dalam kegiatan pembelajaran bertujuan untuk mengukur kompetensi sikap yang telah dikuasai siswa dengan menggunakan rubrik penilaian/catatan observasi dan tindak lanjut. Berikut ini akan dijelaskan gambar mengenai alur pelaksanaan evaluasi pendidikan karakter di SMK Muhammadiyah Juntinyuat Kabupaten Indramayu sebagai berikut.

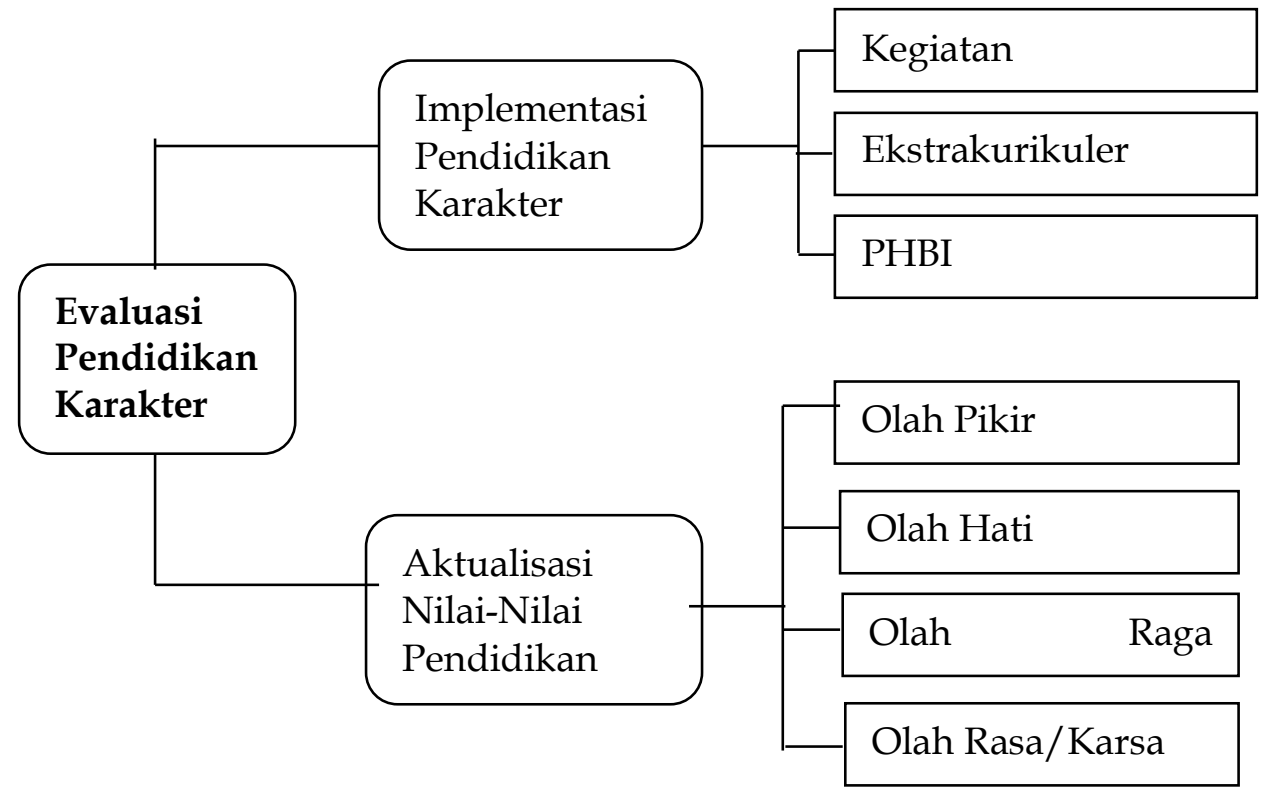

Gambar 1. Model Evaluasi Pendidikan Karakter

Penilaian kompetensi sikap yang dilakan guru di SMK Muhammadiyah Juntinyuat Kabupaten Indramayu menggunakan rubrik penilaian/catatan observasi dan tindak lanjut. Rubrik penilaian/catatan observasi digunakan untuk menilai sikap seseorang. Ada tiga komponen sikap yaitu kognisi, afeksi, dan konasi(Haryati, 2007). Kognisi berkaitan dengan pengetahuan atau kepercayaan seseorang mengenai objek atau stimulus yang dihadapinya, efeksi berkaitan dengan perasaan atau penilaian dalam menghadapi objek tersebut, sedangkan konasi berkaitan dengan kecendrungan untuk berperilaku atau berbuat dengan cara-cara tertentu terhadap objek tersebut dalam penilaian sekala sikap ini guru memiliki sebut journal yang dilampirkan beserta RPP.

Penilaian aktualisasi pendidikan karakter di SMK Muhammadiyah Juntinyuat Kabupaten Indramayu dilakukan dengan(Rosyad \& Zuchdi, 2018) memanfaatkan rubrik penilaian atau catatan observasi guru PAI dan tidak lanjut. Penilaian kompetensi sikap dilakukan oleh guru melalui bekerja sama dengan wali kelas dan guru BK supaya bisa diadakan evaluasi tindak lanjut. 
Catatan mengenai karakter siswa yang dimiliki oleh guru disampaikan pada saat rapat guru dan kepala sekolah untuk mencari solusinya.

Penilaian pendidikan karakter setidaknya menyentuh tiga aspek sebagaimana dijelaskan oleh Lickona(Lickona, 1997) yang menyatakan bahwa

"Component of good characters is: (1) moral knowing (moral awarness, knowing moral values, perspective-taking, moral reasoning, decision-making, and self knowledge): (2) moral feeling (conscience, self esteem, emphaty, loving the good, self control, humanity); and (3) moral action (competence, will, and habit)"

Dapat dilihat bahwa aktualisasi pendidikan karakter dalam kegiatan pembelajaran pada siswa di SMK Muhammadiyah Juntinyuat Kabupaten Indramayu dapat diimplementasikan siswa secara sistematis. Maka untuk pendidikan karakter dapat dievalusi dalam bentuk ulangan harian, rubrik penilaian / catatan observasi, dan tidak lanjut yang telah dirumuskan dalam RPP dan program sekolah untuk mengetahui perilaku siswa.

Berdasarkan hasil wawancara, observasi, dan dokumentasi dengan warga sekolah. Peneliti memperoleh kesimpulan bahwa ada 6 (enam nilai karakter yang telah teraktualisasi dengan baik yaitu nilai demokrasi, religius, kerja sama, peduli sosial, rasa hormat, dan tanggung jawab. Sebagaimana tabel dibawah ini.

Tabel 1. Nilai-Nilai Karakter yang Teraktualisasi dengan Baik

\begin{tabular}{|c|c|c|}
\hline No & $\begin{array}{l}\text { Nilai } \\
\text { Karakter }\end{array}$ & Deskripsi \\
\hline 1 & Kerja Sama & $\begin{array}{l}\text { Kasus positif yang terjadi dalam hal ini adalah saling } \\
\text { menjenguk ketika ada teman yg sakit dan kemauan } \\
\text { siswa untuk saling menolong di lingkungan sekolah. } \\
\text { Namun kasus negatif yang sering terjadi adalah } \\
\text { berkelahi. }\end{array}$ \\
\hline 2 & $\begin{array}{l}\text { Tanggung } \\
\text { Jawab }\end{array}$ & $\begin{array}{l}\text { Dalam pendidikan karakter ini siswa dibimbing untuk } \\
\text { bertanggung jawab secara sadar. Seperti siswa diberi } \\
\text { tugas dan pekerjaan rumah, selain itu ketika siswa } \\
\text { terlambat dan melanggar tata tertib mereka juga dilatih } \\
\text { untuk tanggung jawab menerima sanksi akibat } \\
\text { perbuatanya. }\end{array}$ \\
\hline 3 & Demokrasi & $\begin{array}{l}\text { Perilaku positif dalam hal ini terutama dalam kegiatan } \\
\text { belajar-mengajar adalah siswa dilatih untuk menghargai } \\
\text { pendapat temanya yang berbeda pemikiran dan terbuka } \\
\text { menerima masukan orang lain. }\end{array}$ \\
\hline 4 & Peduli Sosial & $\begin{array}{l}\text { Sikap dan tindakan ini berupa keinginan untuk saling } \\
\text { membantu sesama temanya baik di dalam kelas dan di } \\
\text { luar kelas. }\end{array}$ \\
\hline
\end{tabular}




\begin{tabular}{lll}
\hline 5 & Rasa Hormat & di lingkungan sekolah baik dalam kelas dan diluar kelas \\
& & siswa dilatih untuk bersikap hormat kepada temanya \\
& sesama siswa, pendidik, tenaga kependidikan, tamu dan \\
& lain sebagainya \\
& Perilaku positif dalam hal ini adalah siswa memiliki \\
& kepatuhan untuk sholat berjamaah dan mengikuti \\
& kegiatan bimbingan membaca Alquran. Kasus negatif \\
& yang sering terjadi adalah peserta didik yang membolos \\
& untuk mengikuti sholat berjamaah dan bimbingan \\
& membaca Alquran. \\
\hline
\end{tabular}

Sumber: Kurikulum SMK Muhammadiyah, 2019

Berdasarkan penjelasan tabel tersebut dapat disimpulkan bahwa nilai kedisiplinan dan kejujuran belum teraktualisasi dengan baik karena pengaruh negatif dari lingkungan sosial, media masa, dan penggunaan informasi dan teknologi yang tidak tepat. Nilai-nilai karakter yang sudah teraktualisasi dengan baik hendaknya dipertahankan, namun nilai-nilai karakter yang belum teraktualisasi dengan baik hendak dicari solusi dan tidak lanjutnya.

\section{SIMPULAN}

Pertama, pendidikan karakter dalam konteks Kurikulum 2013 menjadi tanggung jawab semua guru mata pelajaran karena setia KI 1 dan KI 2 mata pelajaran tersebut harus mengembangkan kompetensi sikap yang harus dikuasai oleh peserta didik setelah mengikuti kegiatan pembelajaran,

Kedua, pelaksanaan pendidikan karakter melibatkan semua komponen yang ada baik kepala sekolah, guru mata pelajaran, wali kelas, pembina ekstra kurikuler dan masyarakat sekitar. Pendekatan yang dilakukan oleh pendidik dan tenaga kependidikan dalam mengembangkan karakter siswa dilakukan dengan pendekatan komprehensif

Ketiga, penilaian pendidikan karakter yang dilakukan digunakan dengan penilaian test dan non tes untuk mengetahui nilai-nilai karakter apa saja yang sudah terlaksana dengan baik dan nilai-nilai karakter apa yang belum terlaksana dengan baik.

\section{REFERENSI}

A, D. K. (2012). Pendidikan karakter: Utuh dan menyeluruh. Penerbit Kanisius.

Ahmad, S. (2014). Problematika kurikulum 2013 dan kepemimpinan instruksional kepala sekolah. Jurnal Pencerahan, 8(2).

Arifin, Z. (2013). Cetakan ke 5: Evaluasi Pembelajaran Prinsip, Teknik, Prosedur. Bandung: Remaja Rosdakarya, 61.

Basuki, I., \& Hariyanto, M. S. (2014). Asesmen Pembelajaran. Bandung, PT Remaja Rosda Karya.

Buchory, M. S., \& Swadayani, T. B. (2014). Implementasi program pendidikan karakter di SMP. Jurnal Pendidikan Karakter, (3).

Creswell, J. W. (2015). Penelitian Kualitatif \& Desain Riset Memilih Diantara Lima Pendekatan. Yogyakarta: Pustaka Pelajar. 
Ghony, M. D., \& Almanshur, F. (2012). Metodologi penelitian kualitatif. Jogjakarta: ArRuzz Media.

Haryati, M. (2007). Model dan teknik penilaian pada tingkat satuan pendidikan. Jakarta: Gaung Persada Press.

Heri, G. (2012). Pendidikan karakter konsep dan implementasi. Bandung: Alfabeta.

Kurikulum, P., \& Kemdiknas, P. B. (2011). Pedoman Pelaksanaan Pendidikan Karakter. Jakarta: Pusat Kurikulum Dan Perbukuan Balitbang Kemdiknas.

Lickona, T. (1997). The Teacher's Role in Character Education. Journal of Education. https://doi.org/10.1177/002205749717900206

Moleong, J. (n.d.). Lexy. 2014, Metodologi Penelitian Kualitatif, Bandung: PT. Remaja Rosdakarya.

Mulyasa, E. (2011). Manajemen pendidikan karakter. Jakarta: Bumi Aksara, 165-189.

Mulyasa, E. (2013). Pengembangan dan implementasi kurikulum 2013. PT Remaja Rosdakarya.

Palobo, M., \& Tembang, Y. (2019). ANALISIS KESULITAN GURU DALAM IMPLEMENTASI KURIKULUM 2013 DI KOTA MERAUKE. Sebatik, 23(2), 307-316.

Palunga, R., \& Marzuki, M. (2017). Peran Guru dalam Pengembangan Karakter Peserta DIdik di Sekolah Menengah Pertama Negeri 2 Depok Sleman. Jurnal Pendidikan Karakter, 7(1).

Rosyad, A. M., \& Zuchdi, D. (2018). Aktualisasi pendidikan karakter berbasis kultur sekolah dalam pembelajaran IPS di SMP. Harmoni Sosial: Jurnal Pendidikan IPS. https://doi.org/10.21831/hsjpi.v5i1.14925

Samani, M., \& Hariyanto. (2016). Pendidikan Karakter; Konsep dan Model.

Setiadi, H. (2016). Pelaksanaan penilaian pada Kurikulum 2013. Jurnal Penelitian Dan Evaluasi Pendidikan, 20(2), 166-178.

Sugiyono. (2008). Metode penelitian pendidikan:(pendekatan kuantitatif, kualitatif dan $R \& D)$. Alfabeta.

Sukmadinata, N. S., \& Muchlis. (2000). Pengembangan kurikulum: teori dan praktik. PT Remaja Rosdakarya.

Veithzal, R., \& Murni, S. (2009). Education Management Analisis Teori dan Praktik. Jakarta: PT. RajaGrafindo Persada.

Zuchdi, D. (2008). Humanisasi Pendidikan,(Jakarta: PT. Bumi Aksara. 